\title{
Pragmatism, Ethics and Democracy
}

YEP SEMINAR, May 4th 2011, Rome

\section{Maria Luisi}

\section{(2) OpenEdition}

Electronic version

URL: http://journals.openedition.org/ejpap/799

DOI: 10.4000/ejpap.799

ISSN: 2036-4091

\section{Publisher}

Associazione Pragma

Electronic reference

Maria Luisi, «Pragmatism, Ethics and Democracy », European Journal of Pragmatism and American Philosophy [Online], IV - 1 | 2012, Online since 23 July 2012, connection on 01 May 2019. URL : http:// journals.openedition.org/ejpap/799 ; DOI : 10.4000/ejpap.799

This text was automatically generated on 1 May 2019.

\section{c) (†) $९$}

Author retains copyright and grants the European Journal of Pragmatism and American Philosophy right of first publication with the work simultaneously licensed under a Creative Commons AttributionNonCommercial-NoDerivatives 4.0 International License. 


\title{
Pragmatism, Ethics and Democracy
}

\author{
YEP SEMINAR, May 4th 2011, Rome
}

\section{Maria Luisi}

1 In occasion of this first meeting, YEP invited David Hildebrand and Gregory Pappas to have a seminar on "Pragmatism, Ethics and Democracy." The two professors suggested some texts they wrote as a starting point for the discussion. ${ }^{1}$ In this paper we'll first introduce the main topics presented in their texts and then we'll briefly report the questions we made and Pappas' and Hildebrand's answers.

2 The notion of democracy cannot be reduced to some political mechanisms, but must constantly be reinvented and justified. As Dewey clearly explained, democracy is a "way of life," a "mode of associated living, of conjoint of communicated experience." 2 Democracy, as a way of life, expresses itself in a community of individuals; when a conflict arises, in fact, we often appeal to objective function of a democratic government to regain the balance between the community's members. Hence the notion of objectivity turns out to be very important and deeply connected with that of democracy.

Objectivity is often thought as a proposition's reference to a "pure truth," regarding the latter to be absolute and independent of any particular interest. Such a conception is very ambiguous, insofar as it supposes a person or a government to operate from an abstractly neutral basis, detached from all of his/her feelings and believes. Since it is impossible to reach such an attitude, this interpretation frequently leads to a dogmatic and violent conception of objectivity.

4 On the other side we could endorse a relativistic interpretation of objectivity, thus conceiving the truth as an illusion that should be replaced with the practical need of discussion and conversation. As Richard Rorty writes: "The desire for objectivity - the desire to be in touch with a reality which is more than some community with which we identify ourselves," should be replaced "with the desire for solidarity with that community." ${ }^{3}$ But, even if the notion of objectivity is a masquerade, why is it so important? Why do we appeal to it so frequently? 
5 Is it possible to define objectivity in a new way, independent of any metaphysical commitment? Overcoming the opposition between dogmatism and relativism, Dewey's conception of objectivity represents a middle way, called "pragmatic objectivity." From this standpoint objectivity is not an end-state of inquiry, rather it is a virtue of practice, a regulative ideal for inquiry. Neutrality is a utopia, since we cannot completely free ourselves from our prejudices and we always look at problems from a particular point of view; still, there are points of view which are better than others: "A standpoint which is nowhere in particular is an absurdity. But one may have an affection for a standpoint which gives a rich and ordered landscape rather than for one from which things are seen confusedly and meagerly."

In order for us to gain a better standpoint we need some form of detachment from our position; not the kind of self-abnegation that Descartes suggests, but the "ability to achieve some distance from one's own spontaneous perceptions and convictions." ${ }^{5} \mathrm{We}$ cannot and do not want to reach neutrality, but it is possible to attain that "vital minimum of ascetic self discipline that enables a person to do such things as abandon wishful thinking, assimilate bad news, and discard pleasing interpretations that cannot pass elementary tests of evidence and logic." ${ }^{16}$ Detachment is not an end in itself, but a way of constructing the most powerful arguments, which raise, rather than defeat, the best versions of opponent's arguments.

Question: The conception of pragmatic objectivity claims to be free from any metaphysical commitment and from relativism as well. At the same time, however, this very conception is described by expressions like "to achieve a rich and ordered standpoint," "to discard interpretations that cannot pass tests of evidence" or "to raise the best versions of opponent's arguments." If we cannot refer to an absolute truth, which are the criteria or rules enabling us to determine what is evident, which is the most rich and ordered standpoint or which are the best versions of opponent's standpoint?

Pappas: This is a typical objection to Dewey, which can be properly labeled "contextualist." Contextualism asserts that it is not possible to set up criteria or rules in advance to determine good judgments about a situation. What is useful and good in a particular context may be dangerous in a different one. Some critics may object: "it is not enough to say that good is "what works," because "what works" is always relative to some ends that people may disagree on." This objector is asking for an ultimate standard of evaluation, which is precisely what cannot be provided, according to Dewey. For Dewey "what works" is not what meets a standard but "what fits or resolves this present problematic situation." The concept of "evidence" depends on context as well. You may think Dewey's approach is relativistic, but it is so only in the sense that every judgment refers to a particular situation. Some contextualists regard the language or a conceptual scheme to be the ultimate context, but they do not consider that, even if we have different conceptual schemes, we are always sharing some part of our experiences. For instance, we are sitting on the opposite sides of a table and we have opposite perspectives on the table, but we don't doubt we are in the same room.

In Dewey you can find a normative prescription about knowledge, but such a prescription is not about a rule or a criterion, it is about how you approach the problem. I cannot give you an absolute rule, I do not know in advance which is the solution of the problem, but I can suggest you the best approach to the problem itself. For example, I 
know that to be open-minded is really helpful, but this is not a definitive and dogmatic rule for reasoning.

Hildebrand: You can always doubt you are sharing the same problem with the person you are talking to; that is why detachment is so important. You need to take a distance from your position and to consider other reasons. It's also important to consider the problem in a living context; if you want to share a problem with someone, it can be helpful to have a meal or take a beer with him, because in an abstract discussion it's harder to admit different problems from the ones you are focused on.

Question: For Dewey the ground of pragmatic objectivity is primary experience, namely, the pre-reflective and pre-intellectual basis of our life. "We must, as philosophers, go back to the primitive situations of life that antecede and generate these reflective interpretations." ${ }^{7}$ In Dewey's interpretation experience is constituted by uniqueness and novelty; as such, it is ineffable and deeply connected with feelings. This description of experience refers to the internal life of each person, but there is also a second aspect of the problem, the one described by Peirce through the connection between experience and Secondness. In Peirce's view experience is the "element of brute compulsion in fact,"8 the reaction against something we could never have imagined. ${ }^{9}$ For Peirce experience is pre-reflective as well, but involves something external and independent of the mind. Do you think this conception can be a good basis for pragmatic objectivity?

Pappas: I agree with Peirce: there is a component of Secondness in experience. One difference between Rorty's neo-pragmatism and classical pragmatism is that, according to the latter, there is more in experience than conversation or relation between people. The communal aspect is important, but things have a grain: reality does not allow me to do whatever I want. For Rorty this is not so important, as he asserts we are in conversation also with things. But I think we really react against things and this is Secondness.

Furthermore, besides Secondness, in experience there is also Firstness: things have a Quality. Dewey defines inquiry as the transformation of an indeterminate situation into a determinate one, which amounts to the description of a quality. If we consider democracy, we will find that it requires certain qualities to be realized. Empathy, for instance, is essential for democracy. Dewey writes: "a person entirely lacking in sympathetic responses might have a keen calculating intellect, but he would have no spontaneous sense of the claims of others." ${ }^{10}$ Without feeling the problems of others as equal to our problems there can be neither justice nor democracy, even if we are able to perform a perfect reasoning process. The condition for democratic and moral life is not so much to reach impartiality or get free from any personal feeling, but to have the "best" feelings, namely, to gain those standpoints that provide the agent a rich and broad landscape, upon which to deliberate and to act.

Hildebrand: When we ask if experience can represent a good ground for objectivity, we have to keep in mind that, according to both Dewey and Peirce, experience is not a dimension that belongs to an atomic subject, isolated from the world. We all have a shared self; of course we also a have a private dimension, but most of our experience is shared. There is no private language: if you want to discuss about this room or about what happened today you have to use a public language; you'll use definitions and different arguments that other people will share and understand, that's why language represents a very important and basic form of connection.

Question: do you think there is any connection between pragmatic objectivity and Dewey's conception of nature? As you have rightly pointed out, Dewey explicitly defends a 
"particularist" view of thinking. But he also endorses a naturalistic conception of thought, and he seems to believe that thought - as any other human activity - is conditioned by what kind of living beings we are. If this is true, it should be possible to single out at least some minimal criteria of objectivity from the notion of human nature. Therefore, don't you think that the idea of human flourishing, which is nothing but the interpretation in moral terms of the idea of evolution, could provide a reliable ground of objectivity?

Pappas: Dewey's notion of growth is strange. We could think there is an ultimate standard to human nature and that every man should reach it to complete himself; but a standard like this does not exist. While in his first writings Dewey pays more attention to the self, in the late ones he considers the situation: when you wake up in the morning you do not ask yourself: "How do I grow today?" Rather, you are interested in the particular situation you are living. If we consider the human growing as a process of moralization of human nature, this is a too narrow conception. It is true, Dewey does talk about growing in connection with the problem of education, but education is always connected to particular situations and contexts: he is not referring to an abstract standard for humanity.

Hildebrand: as Dewey observes, there are certain experiences of self-completeness. In a particular situation we can have a more complete feeling of our self, but this does not mean that there is an ideal self to be reached. We also have to remind that flourishing is not only about a single human being, but regards humanity in a wider sense. For instance, in the past centuries we improved our culture, we learned to respect other people and animals, and so on.

Question: may you clarify Dewey's notion of inquiry? Sometimes inquiry is described as a process which tends toward a final result in such a way that it looks like a myth. Is it correct to stress the importance of the process itself in Dewey's conception? Maybe there is an agreement on this point with Hegel's emphasis on the centrality of the process. Which is the role of rules and principles in inquiry?

Pappas: I think Dewey's emphasis on the process can be considered Hegelian. According to Dewey we are always interacting with the situation, and there is no fixed element that should not change. This is true also for rules and principles. For instance, we can find that to be open-minded is in general a better position, but also this conclusion is hypothetical and can be revised. Every experience admits of more stable elements and changing elements. If we are sitting at the table, the floor is the most stable element. But if suddenly there is an earthquake, then the floor becomes precarious and I should look for a different support. A principle in general is the most stable thing we have, but it can change in any moment.

Hildebrand: A principle is something that directs your future activity, like a law in physics (gravitation, for instance). Being fallible, its nature is hypothetical and, as such, it can always be revised. This is true also for rules in ethics; you cannot construct an ethics from an absolute point of view, bun only from a concrete situation.

Question: would you clarify the notion of feeling? Do you regard feeling to be immediate? Maybe there are feelings that seem to be immediate while they are the outcome of an unconscious habit. For instance, some people suffer of a phobia and have a persistent fear of dogs. If a person with such a phobia is talking to someone and suddenly a dog appears, the situation will change and the person will have a feeling of fear. He will think his fear is an immediate feeling, but actually it is a complex and mediated habit.

Hildebrand: We can make a distinction between an experience we had and an experience we know. Imagine you are in your room and unexpectedly there is a tapping 
at your window. You do not know what it is but then you see a little bird making the noise. In this second moment you still have the same experience, but it becomes mediated because you made an inquiry and you recognized the source of the noise.

Pappas: According to Dewey immediate experiences are really important, but he does not deny they can be conditioned by previous experiences. Just because there are always conditions for an experience we cannot reduce the experience itself to its conditions. For example, every experience is in language, but we cannot reduce the former to the latter.

Question: the ground of pragmatic objectivity is experience and the method that leads to experience is called "denotative method." "The experiential or denotative method tells us that we must go behind the refinements and elaborations of reflective experience to the gross and compulsory things of our doings, enjoyments and sufferings - to the things that force us to labor, that satisfy needs, that surprise us with beauty, that compel obedience under penalty."11 Would you clarify the nature and function of the denotative method? It seems to me that in order to communicate we always need to share a common ground and to believe we will eventually reach a comprehensive view of the problem we want to solve. We would never start to inquire if we would not believe in the possibility to reach a common agreement in the future. It seems to me that the very possibility to reach a final comprehensive view is a condition of possibility for communication.

Hildebrand: Pragmatic objectivity is made of habits and virtues. As such, it is a tool for conduct to be used in inquiry. If I suggest a particular conduct to solve a problem, it is because it has a "cash value." If you ask me: "Why?" I'll answer you: "Try it!" We can describe the experience that springs by that conduct as precisely as possible, but experience overflows our description. You have to try to verify if a conduct satisfies you desire. The demonstration cannot be shown on a piece of paper, you have to try it. Human beings work like this: we cannot capture the experience. Does the concept of experience imply a comprehensive view? The point is that I do not know exactly what a comprehensive view should be. We should have a total and comprehensive picture of humanity to gain such a view, but I don't have that! No one has finished living his life, so we all have a partial point of view.

Question: obviously we don't have a comprehensive view yet, but do not we believe it can be reached?

Hildebrand: I don't think we can be sure that this view will ever exist, because we are still working on it. It frequently happens to start a discussion and then to finish it without reaching a common solution.

Pappas: I think a comprehensive view is an abstraction. We can only talk about the present situation. Imagine I'm Muslim and you are Christian: we could quarrel violently but we could also have a beer and laugh together. The problem of a comprehensive view is that we are always an interaction of many different roles: you are a son, a student and a man in the same time, so that you are always considering a problem from a specific point of view.

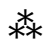

7 A very interesting perspective stands out from this conversation. Objectivity is not the metaphysical end of inquiry, the "thing in itself," but a dynamic concept: it is a way of 
conduct that leads to a good standpoint, the best one to observe this particular present situation.

One last question arises: this standpoint is "good" for a community of men who share the need of dialogue, openness and communication. But, as Hildebrand points out at the end of his paper, "such words will not satisfy those who don't care about transparency, corroboration by shared experience and fallibility of results. They just aren't even in the same game [...]. How do you deal with such hold outs?" How would pragmatic objectivity handle such a situation?

\section{NOTES}

1. The papers are not published yet, so we'll refer to them without quoting directly the text.

2. J. Dewey (1985), The Middle Works (1899-1924), ed. by J. A. Boydston, Southern Illinois University Press, Carbondale and Edwardsville, vol. 9 (MW 9), 93.

3. R. Rorty, (1991), Objectivity, Relativism and Truth: Philosophical Papers I, Cambridge, Cambridge University Press, 39.

4. J. Dewey (1985), The Later Works, 1925-1953, ed. by J. A. Boydston, Southern Illinois University Press, Carbondale and Edwardsville, vol. 6 (LW 6), 14-5.

5. Hildebrand refers here to the work of Thomas Haskell; the quotation is from T. Haskell (1997), Objectivity Is Not Neutrality: Explanatory Schemes in History, Baltimore, John Hopkins University press.

6. LW 6: 14-5.

7. J. Dewey (1985), The Later Works, 1925-1953, ed. by J.A. Boydston, Southern Illinois University Press, Carbondale and Edwardsville, vol. 1 (LW 1), 386.

8. The Essential Peirce. Selected Philosophical Writings, vol. II (1893-1913), edited by Peirce Edition Project, Indiana University Press, Bloomington and Indianapolis, (1998), 182.

9. MS 337s: 5,6, 1904.

10. J. Dewey (1985), The Later Works, 1925-1953, ed. by J. A. Boydston, Southern Illinois University Press, Carbondale and Edwardsville, vol. 7 (LW 7), 270.

11. LW 1: 375-6.

\section{ABSTRACTS}

The first international conference of "Associazione Pragma," that took place in Rome on May 3 and 4 2011, welcomed in its last session the first meeting of YEP (Young European Pragmatists): a group of Pragmatism and American philosophy's young scholars, born in 2011 in cooperation with "Pragma" and the "European Journal of Pragmatism and American Philosophy." The aim of the group is to encourage the cooperation among young European students whose research 
focuses on pragmatism of whatever stripe, and to promote meetings, seminars and publications about pragmatism and its application to contemporary theoretical and practical issues. The group is now well organized in Italy, but we would like to extend our network in Europe, so we invite whoever is interested in the project to contact us, writing to our email address (youngeuropeanpragmatists[at]gmail.com; luisi.mary[at]gmail.com) or visiting us on facebook [facebook.com/group.php?gid=49334734565\&ref=ts].

\section{AUTHOR}

\section{MARIA LUISI}

Università Roma Tre

luisi.mary[at]gmail.com 